\title{
Locus of Control as an Intervening Variable Towards the Behavior of Financial Management
}

\author{
Sarwo Edy Handoyo ${ }^{1 *}$, Herlin Tundjung Setijaningsih ${ }^{1}$, Yunita Valencia ${ }^{1}$ \\ ${ }^{1}$ Faculty of Economics and Business, Universitas Tarumanagara, Jakarta, Indonesia \\ ${ }^{*}$ Corresponding author. Email: sarwoh@fe.untar.ac.id
}

\begin{abstract}
The purpose of this study was to examine and analyze the influence of financial knowledge and income on the behavior of financial management with the locus of control as an intervening variable. The sampling method used in this study is non-probability sampling, which is purposive sampling. Data was collected using a questionnaire. Data analysis used multiple regression. For data processing, the application of SmartPLS version 3.2.8 was used. The results of this study indicate that locus of control mediates the effect of financial knowledge on the behavior of financial management as well as the effect of income on the behavior of financial management.
\end{abstract}

Keywords: locus of control, financial knowledge, income, the behavior of financial management

\section{INTRODUCTION}

Developed countries are a reflection of the progress of their citizens in all aspects of life. Economic indicators are generally used as a reference, such as the amount of per capita income. The higher the income per capita, the more prosperous the people will be, and the more developed the country will be. The income generated by each person can be allocated for consumption, savings, and investment. If the income earned is managed with the right allocation, it will have an impact on the welfare of individuals and society. If a portion of the income is saved, the bank can channel loan funds so that it can enhance the economic activities. Likewise, if a portion of the income is allocated for investment, the economic activities will develop further and can generate returns on investment. Saving and investment behavior has a major contribution to the financial system and affects the progress of a country.

However, if the income is consumed, then do not expect the economic activities to develop rapidly. Companies find it difficult to get loans and investment capital, except with the high cost of capital. This weakens the company's competitiveness as well as the company's growth. The results of a survey conducted by the GoBear platform reveal the financial behavior of Indonesian people. The survey was conducted on respondents aged 18-65 years, who are gender-balanced, have monthly income, and internet access. The results of the GoBear Financial Health Index study reveal an interesting finding, namely that at the age of 35 , Indonesians have not started financial planning, and at the age of 41 , they have just started financial planning related to retirement. The Indonesians feel financially secure on a scale of 7.5 out of 10 . However, only $37 \%$ of them have savings to meet their needs for more than 6 months, if they lose their main source of income [1].
The behavior of financial management anomaly is a widely discussed issue in contemporary financial management. Consumptive behavior of society can endanger the economic security of society in the long run, especially if this consumptive behavior is also carried out by middle and high-income people. It can be relatively understood if consumptive behavior is carried out by people with low income. The allocation of income to meet the consumption of basic needs cannot be avoided or even reduced. As a result, people with low income do not have any balance to save, let alone invest. However, for people who have a locus of control, this is not an obstacle to saving or investing. The limitations of income sources can be balanced by educating them so that they have the financial knowledge to be more selective in consuming and trying to find new sources of income.

Based on previous research, financial knowledge influences the behavior of financial management [2], while the research conducted by Al-Kholilah and Iramani [3] proved that financial knowledge doesn't have a significant influence on the behavior of financial management. Income influences the behavior of financial management [4] whereas Ida and Dwinta's [5] research results show that income does not affect the behavior of financial management. The research conducted by Besri [3] shows that locus of control influences the behavior of financial management.

Based on this background, this study has two objectives. The first is to determine the ability of locus of control in mediating the effect of financial knowledge on the behavior of financial management. The second is to determine the ability of locus of control to mediate the effect of income on the behavior of financial management. 


\subsection{Theoretical Review}

The behavior of financial management of each individual is very diverse. There are relevant theories to explain the determinants of behavior. Ajzen [6] suggested that the theory of planned behavior can be used to predict whether people will do or will not do something. This theory uses three constructs as the antecedents of intention, namely attitudes towards behavior, subjective norms, and perceived behavioral control when conducting the behavior. However, this theory also suggests directly that the perceived ability to control everything can influence behavior to do or not to do something. This theory also explains that attitudes toward behavior, subjective norms and perceived behavioral control can influence one another. The perception of behavioral control is a person's feeling about whether it is easy to manifest a certain behavior and this perception is determined by individual control beliefs regarding the availability and size of the role of resources in form of tools, compatibility, competence, and opportunities (control belief strength) that can support or inhibit the behavior to be predicted [7].

The behavior of financial management is the ability of each person to organize daily planning, budgeting, inspection, management, control, search, and storage of financial assets [3]. The behavior of financial management is related to an individual's financial responsibility in managing his or her finances [8]. An individual's behavior of financial management will be reflected in the search, use, storage, and investment as a form of financial accountability.

Locus of control is related to a person's belief that success in doing everything depends on the person's efforts [9]. Locus of control is the level of individual confidence in selfdetermination [10] [11]. Furthermore, someone, who has an internal locus of control, has control of anything that happens to him/her, while a person who has an external locus of control, that / believes that whatever happens is controlled by the outside forces such as opportunities and good luck.

Financial knowledge is a person's skill in managing finances so that his / her life will be more prosperous in the future [12]. Financial knowledge is a person's ability to make effective decisions with the funds possessed [13]. Based on this opinion, financial knowledge is the ability and skills that a person has in managing finances to become more prosperous.

Income is an economic benefit that has increased in one period, in form of an increase in assets, income, or liabilities that must be paid/decreased so that the equity increases, whereas this increase does not come from an investment [14]. Income in an accounting period is an increase in economic benefits in the form of a decrease in liabilities, income, and addition of assets, whereas the equity has increased, but the increase in equity comes from investors [15]. Based on this opinion, income is the result of work carried out by someone on activities that provide the increased economic benefits.

In an investment decision-making system, it shows that individual characteristics such as locus of control influence the decisions. Individuals who have an internal locus of control need more information in decision making than those who have an external locus of control [16]. Information needed by individuals can be in form of financial knowledge or income. Thus, the knowledge of finance and income will determine locus control and subsequently affect the behavior including the behavior of financial management.

\subsection{Relationship Between Variables}

\subsubsection{Locus of control intervenes in the influence of financial knowledge on the behavior of financial management.}

Based on the planned-behavior theory [6], the behavior is influenced by perceived behavioral control, and perceived behavior control is determined by control belief. Control confidence can be formed by studying everything that can increase the knowledge, such as financial knowledge. AlKholilah and Iramani [3] stated that the control center influences the behavior of financial management, while financial knowledge does not influence the behavior of financial management. Perry and Morris [17] said that the control center and financial knowledge influence the behavior of financial management.

Based on the results of these studies, the control center influences the behavior of financial management, while the variables of knowledge and income still have pro and contra effects on the behavior of financial management. If it is connected to the planned behavior [6], the knowledge possessed by individuals will be able to increase locus of control so that it affects the decisions that are reflected in their behavior of financial management.

Based on this explanation, the following hypothesis can be formulated:

$\mathrm{H}_{1}$ : Locus of control intervenes in the influence of financial knowledge on the behavior of financial management.

\subsubsection{Locus of control intervenes in the effect of income on the behavior of financial management.}

A person's behavior in financial management is influenced by the locus of control and income. In line with the plannedbehavior theory [6], locus of control owned by individuals can mediate the effect of income on the behavior of financial management. Hilgert, et al. [18] stated that lowincome respondents are more likely to report bill payments not on-time compared to high-income individuals. Individuals with high income tend to behave more wisely and are responsible for managing their finances. Besides, Aizcorbe, et al. [19] stated that low-income families are less likely to show saving behavior. Individuals who have wise and responsible in the behavior of financial management will save, make budgets, and control their spending.

Al-Kholilah and Iramani's research [3] stated that only the control center influences the behavior of financial management while the income does not. Ida and Dwinta's 
research [5] stated that income does not affect the behavior of financial management. Based on the planned-behavior theory and the research results, it is possible that if the locus of control is used as an intervening variable, then the income will influence the behavior of financial management Based on this explanation, a hypothesis can be made as follow:

$\mathrm{H}_{2}$ : Locus of control intervenes in the effect of income on the behavior of financial management.

\subsection{Research Framework}

Based on the theory and the relationship between the variables described above, this research framework can be developed as follow.

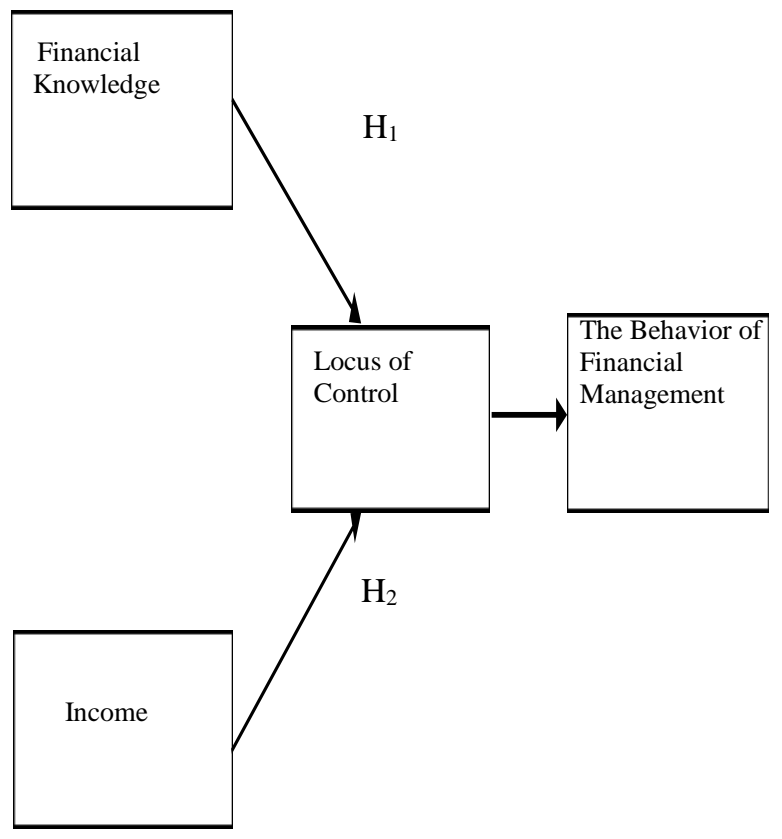

Figure 1 Research Framework

Source: Compiled from various references

\subsection{Methodology}

This research is the quantitative type with a nonexperimental research design. The population of this research is people who live in West Jakarta, Indonesia, as employees, entrepreneurs, students who are working or selfemployed. The research sample was determined using a non-probability sampling method with a purposive sampling technique with the criteria that respondents who live in West Jakarta have after-tax income between IDR 5 10 million per month. In this study, the sample size is 100 people. The data collection technique uses a questionnaire. In this study, the questionnaire was submitted to respondents via Google Form. The answer to each question to measure the variables in this study used an ordinal scale of 1-5 consisting of the scales of 1-strongly disagree, 2disagree, 3-neutral, 4-agree, and 5-strongly agree. The analytical method used is multiple regression. Data processing used SmartPLS version 3.2.8.

In the variable of the behavior of financial management, the indicators are: making adequate financial records; recording daily receipts and expenses/expenditures chronologically; arranging a budget so that it can be used for 1 month; conducting a price survey before shopping; expenses are less than income; some expenses that are incurred should not be needed, and allocating some fund for unexpected expenses in savings [3]. In the variable of financial knowledge, the indicators are: financial knowledge is very important for the welfare and success of a person both now and in the future; the regional minimum wage only applies to low-level employees in a company; the benefits of financial budgeting are the direct use of money and waste avoidance; the level of education in the world of one's work has a very significant effect on one's income [13]. In the income variable, the indicators are sufficient income for daily needs; having more income to save; having more income to invest; managing the income efficiently; the income earned is by responsibilities [15]. In the locus of the control variable, the indicators are: financial arrangements are driven by life around; being able to do whatever is already in the mind; what happens in the future depends on oneself, and having little control over what happens to yourself [9]. The answer to the statement of each variable's research indicator uses a Likert-scale between 1 to 5 . Score 1 indicates strongly disagree, and score 5 indicates strongly agree.

\section{THE RESULTS OF DATA ANALYSIS AND DISCUSSION}

\subsection{Descriptive Statistics of Respondents' Demographics}

Table 1 presents the characteristics of respondents based on age. Based on this data, from the total respondents as many as 100 people, $82 \%$ were $18-25$ years old, $15 \%$ were $26-33$ years old, and only $3 \%$ were over $33-41$ years old. The majority of respondents who are young (aged 18-25 years) will be able to provide an overview of their behavior of financial management related to the use of their income. Furthermore, Table 1 shows the gender of the respondents. Based on this table, $61 \%$ are females and $39 \%$ are males. It is interesting to observe the respondents regarding their financial behavior. The analysis will be carried out if the respondent is unknown. If the respondents are genderbalanced, it is relatively more complicated to analyze between the independent and the dependent variable. 
Table 1 The Characteristics of Respondents

\begin{tabular}{|l|l|l|l|}
\hline \multicolumn{3}{|c|}{ Age } & \multicolumn{2}{|c|}{ Gender } \\
\hline \begin{tabular}{|l|l|l|}
\hline Interval \\
(years)
\end{tabular} & $\begin{array}{l}\text { Amount } \\
(\%)\end{array}$ & Type & $\begin{array}{l}\text { Amount } \\
(\%)\end{array}$ \\
\hline $18-25$ & 82 & Female & 69 \\
$26-33$ & 15 & Male & 31 \\
$34-41$ & 3 & & \\
\hline 41 & - & & \\
\hline \multicolumn{3}{|c|}{ Employment } \\
\hline \multicolumn{2}{|c|}{ Type } & Amount \\
& $(\%)$ \\
\cline { 1 - 2 } Staff & 67 \\
Entrepreneur & 33 \\
\hline
\end{tabular}

Source: Processed Primary Data

Table 1 also shows the gender of the respondents. Based on the table, $61 \%$ are females and $39 \%$ are males. It is interesting to observe the majority of respondents, namely the females in their financial behavior. The table also shows the composition of respondents by their types of work. Based on this, the majority of respondents were $67 \%$ as employees, while the rest were $33 \%$ as entrepreneurs. The results of this study will be colored with an overview of the behavior of financial management of employees compared to entrepreneurs.

Based on this table, the behavior of financial management studied has some characteristics, namely majority respondents had the after-tax income between IDR 5 - 10 million, the majority age was 18-25 years old, the majority gender is female, and the majority job type was an employee

\subsection{Convergent Validity Test}

To assess the results of convergent validity test, loadingfactor, common factor, communality, and average variance extracted (AVE) can be used. The test results are based on the loading-factor, whereas each indicator is considered valid if it has the value $>0.7$. However, for early-stage research, a loading-value between $0.5-0.6$ is considered sufficient, or in the allowed range. The loading factor value is at a sufficient level or in the allowed range, which is > 0.5 . Meanwhile, the test results with a value of communality $>0.5$ and the average variance extracted $(\mathrm{AVE})>0.5$, are required so that the analysis of these factors can be done [20].

In this study, the convergent validity test results have the smallest loading-factor of 0.729 for the indicators of the behavior of financial management. This means that the indicators of the variables used in this study are valid or have met the requirements of convergent validity. The values obtained for communality and AVE are greater than 0.5 so that the indicators in this study were proven to measure the latent variable constructs. The results of the convergent validity test, which includes loading-factor, average variance extracted (AVE), and communality show that all indicators are valid.

\subsection{Discriminant Validity Test}

According to Irwan and Khaeryana [21], an indicator is declared the most valid if it has the highest factor-loading in the intended construct, compared to that in other constructs. In this study, the biggest factor-loading of the income variable $\left(\mathrm{X}_{2}\right)$ is 0.865 , compared to the locus of the control variable $\left(\mathrm{X}_{3}\right)$ factor-loading which is 0.854 , the financial knowledge $\left(\mathrm{X}_{1}\right)$ factor-loading which is 0.850 , and then the behavior of financial management (Y) factorloading which is 0.841 .

\subsection{Reliability Test}

The reliability test in this study uses two methods, namely Cronbach's Alpha and composite reliability. According to Irwan and Khaeryana [21], the reliability test is carried out to measure the consistency of measuring instruments of a research concept. The value of Cronbach's alpha and composite reliability must be higher than 0.7 , but the value of 0.6 is still in the allowed or acceptable range.

In this study, the Cronbach's alpha value for all variable constructs is greater than 0.7 so that each variable could be considered reliable. The composite reliability for the constructed variable is above 0.7 so that each variable can be considered reliable as well. The results of the reliability tests, both Cronbach's Alpha, and composite reliability show that each variable has met the reliability requirement.

\subsection{Test the Coefficient of Determination $(R-$ Square $\left(R^{2}\right)$}

The coefficient of determination test is carried out to see how much the ability of the independent variable to influence the dependent variable. The $\mathrm{R}^{2}$ value in the behavior of the financial management variable is 0.816 , which means that $81.6 \%$ variation in the behavior of the financial management variable can be explained by the variation in financial knowledge, income, and locus of control variables. Meanwhile, the remaining $18.4 \%$ variation in the behavior of financial management can be explained by other variables out of the scope of this research.

\subsection{Hypothesis Testing}

The t-test is conducted to determine the effect of the independent variable and/or mediation on the dependent variable. The mediation variable shows a significant level if the $\mathrm{t}$-statistical value is greater than 1.96 for the two-tailed hypothesis testing, and 1.64 for the one-tailed hypothesis testing, with the $5 \%$ alpha $(\alpha)$. Table 2 below shows the statistical t-test results for each variable. 
Table 2 Results of Intervention Effect Estimation - Path Coefficient

\begin{tabular}{|l|l|l|l|l|l|}
\hline & $\begin{array}{l}\text { Original } \\
\text { Sample } \\
(\mathrm{O})\end{array}$ & $\begin{array}{l}\text { Sample } \\
\text { Mean } \\
(\mathrm{M})\end{array}$ & $\begin{array}{l}\text { Standard } \\
\text { Deviation } \\
(\mathrm{STDEV})\end{array}$ & $\begin{array}{l}\text { T Statistics } \\
(\mid \mathrm{O} /\end{array}$ & $\begin{array}{l}\text { P- } \\
\text { STDEV })\end{array}$ \\
\hline $\begin{array}{l}\text { FK- } \\
\text { LoC- } \\
\text { BFM }\end{array}$ & 0.086 & 0.085 & 0.040 & 2.140 & 0.033 \\
\hline $\begin{array}{l}\text { I- } \\
\text { LoC- } \\
\text { BFM }\end{array}$ & 0.165 & 0.156 & 0.055 & 2.996 & 0.003 \\
\hline
\end{tabular}

Note:

FK-LoC-BFM: Financial knowledge-Locus of Control-The Behavior of Financial Management

I-LoC-BFM: Income-Locus of Control-The Behavior of Financial Management

Source: SmartPLS output version 3.2.8

Based on the table, using a confidence level of $95 \%$, the pvalue is $0.033(<0.05)$ for the financial knowledge - a locus of control - the behavior of financial management. Thus, H1 was accepted, that is, locus of control intervenes the effect of financial knowledge on the behavior of financial management. This result indicates that locus of control as an intervening variable can strengthen the influence of financial knowledge on the behavior of financial management.

At the $95 \%$ confidence level, the p-value is 0.03 for the income - locus of control - the behavior of financial management. Thus, $\mathrm{H} 2$ was accepted, that is, locus of control can intervene the effect of the income on the behavior of financial management. This result indicates that the locus of control variable can strengthen the influence of income on the behavior of financial management.

\subsection{Discussion}

The discussion of the results of this study was carried out by comparing the results of hypothesis testing with previous research and relevant theories.

\subsubsection{The influence of financial knowledge on the behavior of financial management with the locus of control as an intervening variable.}

Based on the results of data analysis, it shows that at the 95\% confidence level, locus of control significantly intervenes in the effect of financial knowledge on the behavior of financial management, because the $\mathrm{p}$-value is $0.033(<0.05)$. This result indicates that $\mathrm{H} 1$ was accepted, meaning that the locus of control as an intervening variable can strengthen the influence of financial knowledge on the behavior of financial management. This result is in line with the planned behavior theory put forward by Ajzen [6]. The individual's belief that his or her success in performing the behavior of financial management depends on the efforts to acquire financial knowledge. The higher the financial knowledge is, the more confident someone will succeed so that this belief is what drives the more appropriate the behavior of financial management. The result is also in line with the opinion of Handoyo [16], that the higher financial knowledge means that someone has adequate information, which will determine the high locus of control as a reflection of its characteristics. This will provide a strong impetus for individuals to shape their behavior in financial management. Thus, the result of this study supports the theory of planned behavior.

\subsubsection{The effect of income on the behavior of financial management with the locus of control as an intervening variable.}

Based on the data analysis that has been done, it shows that at the $95 \%$ confidence level, income significantly mediates the effect of financial knowledge on financial management behavior, because the p-value is $0.003(<0.05)$. These results indicate that $\mathrm{H} 2$ is accepted, meaning that the locus of control variable as an intervening variable can strengthen the effect of income on the behavior of financial management. This result is in line with the planned behavior theory put forward by Ajzen [6]. An individual's belief that his or her success in performing the behavior of financial management depends on the efforts to earn the income. The greater the income is, the more confident someone will succeed so that this belief is what drives the more appropriate the behavior of financial management. The result is also in line with the opinion of Handoyo [16], that the bigger income means someone has adequate information, which will determine the high locus of control as a reflection of its characteristics. This will provide a strong impetus for individuals to shape their behavior in financial management. The result of this study is in line with the theory of planned behavior.

\section{CONCLUSIONS AND SUGGESTIONS}

Based on the results of the analysis and discussion carried out, it can be concluded as follows. Locus of control can intervene in the effect of financial knowledge on the behavior of financial management. The influence of financial knowledge on the behavior of public financial management can be strengthened by the presence of a locus of control. Someone's financial knowledge is a valuable asset to build self-confidence and can control consumptive behavior. Locus of control can intervene in the effect of income on the behavior of financial management. The influence of income on the behavior of public financial management can be strengthened by the presence of a locus of control. The amount of income a person has is a valuable asset to build self-confidence in being able to control his or her consumptive behavior.

People need to increase their knowledge and income to foster self-confidence to reduce consumptive behavior and increase saving and investment behavior. The next 
researcher can use other independent variables and mediations that are thought to affect the behavior of financial management, such as gender and type of work. Regulatory institutions such as the Financial Services Authority (OJK) are advised to increase public financial literacy and motivate them to work harder to increase their income so that it can improve the consumptive behavior of most community members.

\section{REFERENCES}

[1] Fahrizal, R.: Survei Platform GoBear Ungkap Perilaku Keuangan Masyarakat Indonesia. https://infokomputer.grid.id/read/121903700/surveiplatform-gobear-ungkap-perilaku-keuangan-masyarakat -indonesia. Kamis 31 Oktober. 17.38 WIB. (2019).

[2] Besri \& Djamarah, S.: Pola Komunikasi Orang Tua dan Anak dalam Keluarga. Jakarta: PT Rineka Cipta. (2016).

[3] Al-Kholilah, N. \& Iramani.: Studi The behavior of financial management pada Masyarakat Surabaya, Journal of Business and Banking, 3(1): 69-80. (2013).

[4] Herdjiono, Irine \& Damanik, L. A.: Pengaruh Financial Attitude, Financial Knowledge, Parental Income terhadap The behavior of financial management . Jurnal Manajemen Teori dan Terapan Tahun 9. No. 3, Desember. (2016).

[5] Ida \& Dwinta.: Pengaruh Locus Of Control, Financial Knowledge, Income terhadap The behavior of financial management . Jurnal Bisnis Akuntansi.12(3). 131-144.

http://www.stietrisakti.ac.id/jba/JBA12.3Desember2010 /1_artikel_JBA12.3 Desember210.pdf, 03 Maret 2015. (2010)

[6] Ajzen, I.: The Theory of Planned Behavior, Organizational Behavior, and Human Decision Processes, vol. 50, no. 2, pp. 179-211. (1991)

[7] Ajzen, I. \& Fishbein, M.: The influence of Attitudes on Behavior. In Albarracin, D. (2005).

[8] Dew, J., \& Xiao, J. J. (2016). The behavior of financial management Scale: Development and Validation. Journal of Financial Counseling and Planning. Volume 22, 43-59.

[9] Rotter, J.B.: Generalized Expectancies for Internal Versus External Control Enforcement versus External Control Reinforcement, Psychology Monographs: General Applied. Journal Of Business Studies. Vol. 2(1). (1966).

[10] Kreitner, R., \& Kinicki, A.. Organizational Behavior (10th ed.). New York, NY: McGraw-Hill/ Irwin. (2013).
[11] Robbins, Stephen P \& Judge, Timothy A.: Organizational Behavior Edition 15. New Jersey: Pearson Education. (2013).

[12] Chen, H. \& Volpe, R. (2015). An Analysis of Personal Financial Literacy Among College Students, Financial Services Review, 7(2):107-128.

[13] Manurung, S. P. (2015). The Influence of the Entrepreneurial Mindset Towards Product Innovation: (Case Study on Moms Bakery in Bandung). Proceedings 2nd International Conference for Emerging Market-Bali, January 22-23. 76-82.

[14] Kartikahadi, H. (2017). Akuntansi Keuangan Berdasarkan SAK Berbasis IFRS. Jakarta: IAI.

[15] Martani, D. (2016). Akuntansi Keuangan Menengah Berbasis PSAK. Jakarta: Salemba Empat.

[16] Handoyo, S. E. and Setijaningsih, H.T. Usage of Investment Assessment and Decision Sytems: The Impact of Investor Characteristics. Advances in Economics, Business and Management Research, Volume 145. Published by Atlantis Press SARL. Pp 405-411. Publication Date 29 June 2020. ISBN 978-946252-980-9. ISSN 2352-5428. DOI https://doi.org/10.2991/aebmr.k.200626.069. (2020).

[17] Perry, V. G., \& Morris, M. D. "Who is in Control? The Role of Self Perception, Knowledge, and Income in Explaining Consumer Financial Behavior".The Journal of Consumer Affairs, Vol. 39, No. 2, pp. 299-313. (2005)

[18] Hilgert, M. a., Hogarth, J. M., \& Beverly, S. G. Household Financial Management: The Connection between Knowledge and Behavior. Federal Reserve Bulletin, 106 (November 1991), 309-322. https://doi.org/10.1093/rfs/hh v072. (2015).

[19] Aizcorbe, A. M.; Kennickell, A.B. \& Moore, K.B.: Recent Changes in U.S Family Finances: Evidence from the 1998 and 2001 Survey of Consumer Finances. Federal Reserve Bulletin, 89 (January), pp. 132. (2003).

[20] Yemima. Intensi Kewirausahaan Mahasiswa Studi Perbandingan Mahasiswa Eksakta Dengan Mahasiswa Non-Eksakta UTA'45 Jakarta. Journal of Business Studies.Vol. 2(1). (2016).

[21] Irwan dan Khaeryana. Analisis Faktor-Faktor yang Memotivasi Mahasiswa dalam Berwirausaha (Studi Kasus pada Universitas Muhammadiyah Malang). Journal of Business Studies. Vol. 2(1). (2015). 